\title{
PRELIMINARY REPORT ON THE LACUSTRINE STRATA OF THE SANFRANCISCANA BASIN IN NORTHERN MINAS GERAIS, BRAZIL
}

\author{
Jonathas S. Bittencourt ${ }^{1,2}$, Pedro L. C. R. Vieira ${ }^{1}$, Raphael M. Horta, André G. Vasconcelos ${ }^{1,2}$, \\ Natália C. A. Brandão ${ }^{2,3}$, Angelo Dos Santos ${ }^{4}$,Luiz Guilherme Knauer ${ }^{1}$
}

\author{
${ }^{1}$ Instituto de Geociências, Universidade Federal de Minas Gerais, Av. Presidente Antônio Carlos 6627, 31270-901, Belo Horizonte, Minas Gerais, Brazil. \\ jsbittencourt@ufmg.br (*autor correspondente). \\ ${ }^{2}$ Laboratório de Paleontologia e Macroevolução, Centro de Pesquisas Professor Manoel Teixeira da Costa, Instituto de Geociências, UFMG. \\ ${ }^{3}$ Programa de Pós-graduação em Zoologia, Instituto de Ciências Biológicas, UFMG. \\ ${ }^{4}$ Department of Earth and Planetary Sciences, McGill University, Montréal, Quebec H3A 0E8, Canada.
}

Received on March 18, 2019; accepted on October 13, 2019

Abstract: We report new data on the geology and the fossil record of the Sanfranciscana Basin in sites to the north of the traditionally explored localities within Minas Gerais. The strata in the new explored area are formed by distinct lithologies, encompassing pelitic rocks with caliche levels and metric bodies of cross-bedded sandstone towards the top, similar to the fluviolacustrine beds of the Areado Group in the southern portions of the basin. Also similar to other regions of the São Francisco Craton, the deposits of the Sanfranciscana Basin studied herein lie discordantly to the rocks of the Bambui Basin. We preliminarily report neopterygian fish scales, little informative archosaurian bones and an association of the ostracods IlyocyprisFossocytheridea. This ostracod association is registered for the first time in the Cretaceous of the Sanfranciscana Basin. The ostracods have been collected from the lacustrine, vertebrate-bearing rocks cropping out in Lagoa dos Patos and Coração de Jesus. The cytherideid Fossocytheridea assigns a minimal Aptian age to its bearing rocks. Its association with /lyocypris was also reported in Upper Cretaceous oligohaline paleoenvironments in Brazil and Argentina, indicating similar depositional conditions to the strata reported in this paper. The putative affinities of the specimens of the Sanfranciscana Basin with F. ventrotuberculata, and their association with /lyocypris, raise the hypothesis of a younger age for some levels of that basin in northern Minas Gerais, perhaps ranging into the Late Cretaceous.

Keywords: Ostracoda, Archosauria, Areado Group, Cretaceous, Gondwana

\section{INTRODUCTION}

The Sanfranciscana Basin corresponds to the most recent, massive depositional event over the São Francisco Craton. Despite its wide geographical extension, the fossil record is poorly known -. Most specimens have been recovered from the lacustrine and fluvial strata of the Areado Group at Planalto Mata da Corda, in the central-northwestern region of Minas Gerais State . In fact, most research conducted since 1950 's has focused on this area.

The recent discovery of sauropod and theropod dinosaurs in northern portions of the Sanfranciscana Basin within Minas Gerais has drawn attention to its importance as a window to the Cretaceous ecosystems on the central-western Gondwana. These discoveries may help to understand the paleogeography and paleobiota of the inner portion of the São Francisco Craton under influence of the opening of the Atlantic Ocean. Yet, sampled material for biostratigraphic correlation within the Sanfranciscana Basin and with other sedimentary basins worldwide is rather poor. Recent studies partially refined the age of the Areado Group, including a Valanginian-Aptian range for the Quiricó Formation - , and a possible Albian to Coniacian time span to the overlying Três Barras Formation (Maraschin et al., 2016).

The data discussed in this paper will help to improve the correlation between south and north outcrops of the Sanfranciscana Basin.

\section{GEOLOGICAL SETTING}

The Sanfranciscana Basin sensu Campos \& Dardenne- corresponds to the Phanerozoic sections of the São Francisco Basin as defined by Alckmin \& Martins-Neto Lying discordantly to the rocks of the Bambuí Basin, which is represented in the studied area by the Serra de Santa Helena, Lagoa do Jacaré and Serra da Saudade formations, it spans over ca. $150,000 \mathrm{~km} 2$ in southeast and northeast portions of Brazil --. Yet, only the outcrops within Minas Gerais State have yielded fossils until now (Bittencourt et al., 2015).

The lowest strata of the Sanfranciscana Basin (Santa Fé Group, Paleozoic) have glacial origins - . The Cretaceous sections (Figure 1-2), which are the bulk of the strata within that basin, are assembled into the Areado, Mata da Corda and Urucuia groups. The former encloses the non-fossiliferous Abaeté Formation (alluvial fan, braided fluvial paleoenvironment) at the base, the

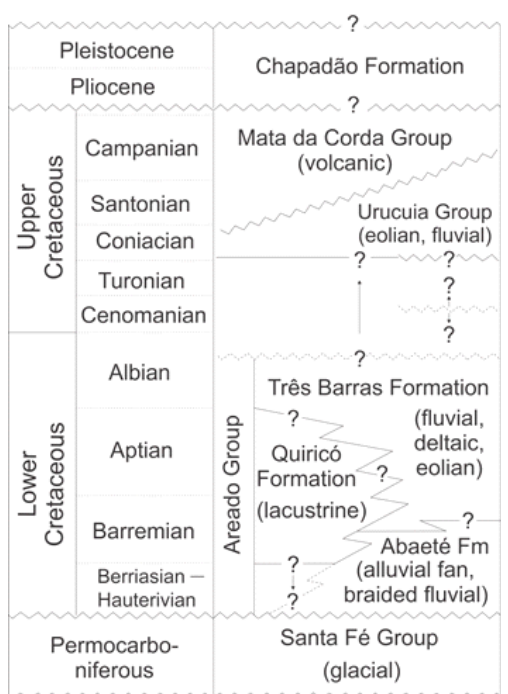

Figure 1 - Stratigraphy of the Sanfranciscana Basin. Modified from several sources. 
predominantly lacustrine Quiricó Formation and the upper Três Barras Formation, deposited in fluvial, deltaic, and eolian environments (Campos \& Dardenne, 1997; Sgarbi et al., 2001; Figure 1).

In southern portions of the Sanfranciscana Basin (Figure 2), the Areado Group is capped by the volcanic rocks of the Mata da Corda Group (Figure 1). The latter is dated minimally as Turonian, based on distinct radiometric dating techniques (see Maraschin et al., 2016, for review). The Upper Cretaceous sandstones of the Urucuia Group crops out further north, and were deposited in eolian and fluvial context (Campos \& Dardenne, 1997; Sgarbi et al., 2001). The Chapadão Formation sensu Campos \& Dardenne (1997) includes Cenozoic, reworked, unconsolidated sediments spread over the Sanfranciscana Basin (Campos \& Dardenne, 1997).

The Areado Group is especially noticeable due to its fossil record. The paleobiota of the Quiricó Formation includes so far charophytes, continental palynomorphs, gymnosperms and angiosperms, ostracods, 'conchostracans', insects, elasmobranchs, actinopterygians, the coelacanthiform Mawsonia and dinosaurs (Scorza \& Silva Santos, 1955; Barbosa, 1965; Cardoso, 1971; Santos, 1971; Lima, 1979; Silva Santos, 1985; Martins-Neto, 1996; Duarte, 1997; Carvalho \& Kattah, 1998; do Carmo et al., 2004; Carvalho \& Maisey, 2008; Zaher et al., 2011; Bittencourt et al., 2015, 2018; Carvalho \& Santucci, 2018; Leite et al., 2018). Fossils recovered from the Três Barras Formation include enigmatic marine microfossils, notably radiolarians, in very restricted horizons (Kattah \& Koutsoukos, 1992; Pessagno Jr. \& Dias-Brito, 1996; Dias-Brito et al., 1999), and dinosaur footprints (Carvalho \& Kattah, 1998).

The ages of the Areado and Urucuia groups are poorly constrained. The Quiricó Formation has been considered Barremian-Aptian by several authors (see Bittencourt et al., 2015), mainly based on the occurrence of terrestrial palynomorphs (Lima, 1979; Arai et al., 1995) and ostracods (do Carmo et al., 2004). Yet, Leite et al. (2018) found a basal range of the podocopidan Cypridea hystrix Krömmelbein, 1962 in the classical locality 'Fazenda Tereza', near João Pinheiro (Figure 2), assigning a Valanginian age to that level. This assignment confirmed a previous hypothesis according to which the lower levels of the Quiricó Formation are pre-Barremian (Kattah, 1991; Sgarbi, 1997).

The lower member of the Três Barras Formation has been recently dated as Albian-Coniacian based on K-Ar dating of authigenic K-feldspar (Maraschin et al., 2016). This age is different from that hinted by the enigmatic radiolarians found within the same levels, which suggested Lower Cretaceous (possibly Barremian-Aptian) for the early deposition of the Três Barras Formation (Pessagno Jr. et al., 1997; Dias-Brito et al., 1999). This age incongruency is not entirely unexpected, both because of the stratigraphically problematic position of the marine microfossils (Sgarbi et al., 2001), and the post-burial age of the diagenetic potassic minerals, which can be younger than the time of deposition (Hagen et al., 2001; Maraschin et al., 2016).

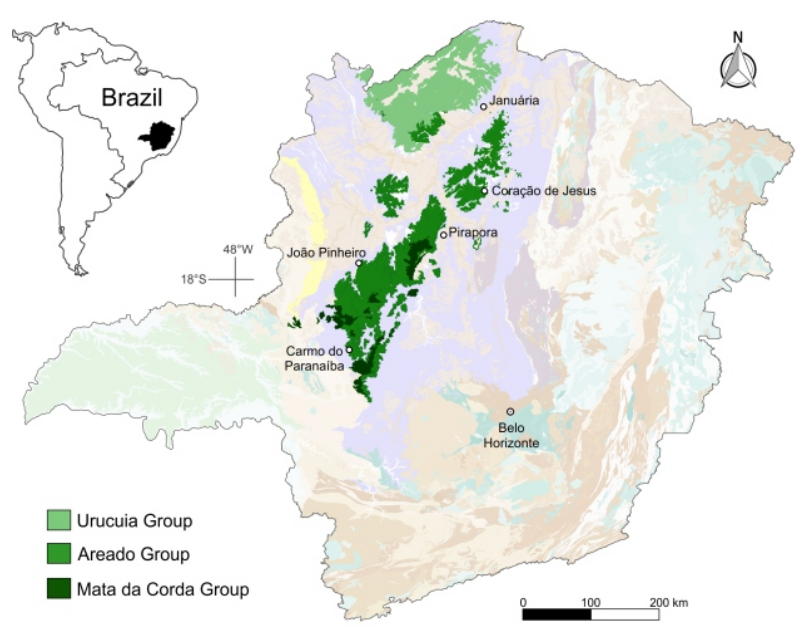

Figure 2-Geological map of Minas Gerais, highlighting the Cretaceous sections of the Sanfranciscana Basin. Modified from several sources (Chaves \& Andrade, 2013; Costa et al., 2013; Knauer et al., 2013; Romano et al., 2013; Uhlein et al., 2013; CPRM/CODEMIG, 2014).

\section{MATERIALAND METHODS}

We surveyed outcrops of the Sanfranciscana Basin in the region of Lagoa dos Patos and Coração de Jesus, north Minas Gerais (Figure 3), following previously published geological maps of the area (Chaves \& Andrade, 2013; Knauer et al., 2013). The sedimentary data collected therein were used to design a stratigraphic section of the region (Figure 4).

The ostracods were recovered after disaggregation of 60 g of sedimentary rock from each sampled level with oxygen peroxide $30 \%$; screen-washed with $90 \mu \mathrm{m}, 150$ $\mu \mathrm{m}, 250 \mu \mathrm{m}$ and $1 \mathrm{~mm}$ mesh sieves and collected under stereomicroscope. The most relevant specimens received a carbon coat and were then visualized with a JEOL JSM-6510 electron scanning microscope. All the specimens discussed below are housed at the Instituto de Geociências, Universidade Federal de Minas Gerais (IGCP), Belo Horizonte, Brazil.

\section{RESULTS AND DISCUSSION}

\section{Geology of the area}

In the region studied for this paper (Figure 3), the rocks here ascribed to the Areado Group crop out as continuous deposits at 700-800 m of altitude. Similar to previous reports on the geology of the region (PiresDomingues, 2009), we identified three sets of lithologies. The most common of them (Figure $4 \mathrm{~A}-\mathrm{C}$ ) is formed by silty claystones, clayey siltstones, mudstones and greywacke sandstones with carbonate cement. Occasionally, mudstones bear small calcite veins and carbonate concretion grown over silty intraclasts. Most fossils have been recovered from this lithology, including little informative archosaur bones, fish scales and ostracods (see below). 


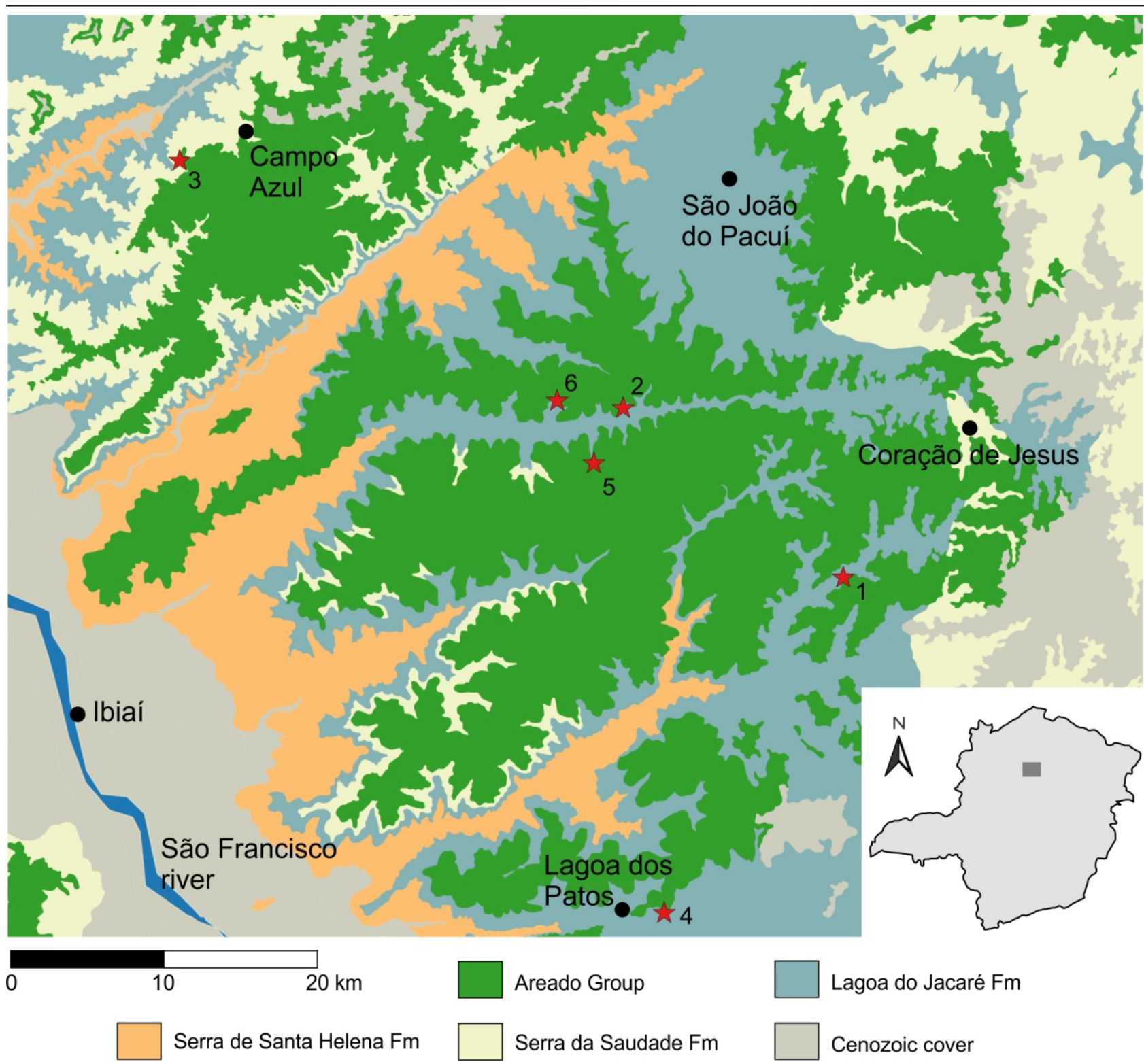

Figure 3-Geological map of the studied area in north Minas Gerais. Stars indicate fossil localities discussed by (1) Zaher et al. (2011), (2) Bittencourt et al. (2017), (3) Carvalho \& Santucci (2018), (4-6) this paper. Fm: Formation. Map modified from several works (Chaves \& Andrade, 2013; Costa et al., 2013; Knauer et al., 2013; Uhlein et al., 2013).

The second lithology encompasses repetitive $30 \mathrm{~cm}$ to 4 $\mathrm{m}$ intercalation of claystone/siltstones/caliche, or claystone/sandstones with horizontal lamination (Figure $4 \mathrm{~A})$. The claystone/sandstones intercalation is composed of spherical to subspherical quartz grains at silt and fine sand size, and claystone laminae. Lamination within this lithology is variably thick. Each caliche lamina is no thicker than $3 \mathrm{~cm}$. Siltstone, claystone and sandstone laminae are no thicker than $5 \mathrm{~mm}$.

The third lithology (Figure 4A, D-E) comprises massive, poorly sorted sandstones, with frequent quartz and rare feldspar grains. The sandstone shows horizontal, tabular cross-bedded or trough-bedded stratification, silty and clayey matrix and carbonate cement. In upper sandy levels, the matrix is scanty or absent.

The set of lithologies described above support the interpretation of the paleoenvironment as predominantly lacustrine with episodic influx of fluvial sediments, under the influence of desertic climate (playa lake), similar to the deposits of the Areado Group in the Planalto Mata da Corda (Sgarbi et al., 1993; Campos \& Dardenne, 1997; Sgarbi et al., 2001; Mescolotti et al., 2015). The assignment of these beds in north Minas Gerais to the Quiricó Formation has been hinted by some authors (Zaher et al., 2011; Bittencourt et al., 2017; Carvalho \& Santucci, 2018). Yet, additional data on the stratigraphic distribution of the lacustrine deposits in that region and its fossil content are required to confirm this hypothesis.

\section{Fossil Ocurrences}

Isolated neopterygian scales, archosaur bones and ostracods have been recovered in several localities of the area. The neopterygian scales (most probably belonging to lepisosteid) are similar to those reported by Bittencourt et al. (2017), from the locality 2 (Figure 3). They are abundant in the horizon V, rarer in I, III-IV, and absent in the horizon II. None specimen has been found complete. 
The archosaur bones (Figure 4F-K) were found as crushed and fractured pieces scattered on the ground. In thin section, they show dense Haversian replacement of several generations (Figure 4F). In some specimens, the internal architecture was partially destroyed by the infilling and crystallization of calcite during diagenesis (Figure 4G). Their anatomy is not informative. The identification as archosaur is compatible with more complete and informative theropod and sauropod dinosaurs previously found in the area, including localities near Coração de Jesus (Zaher et al., 2011; Silva, 2013) and Campo Azul (Figure 3) (Carvalho \& Santucci, 2018).
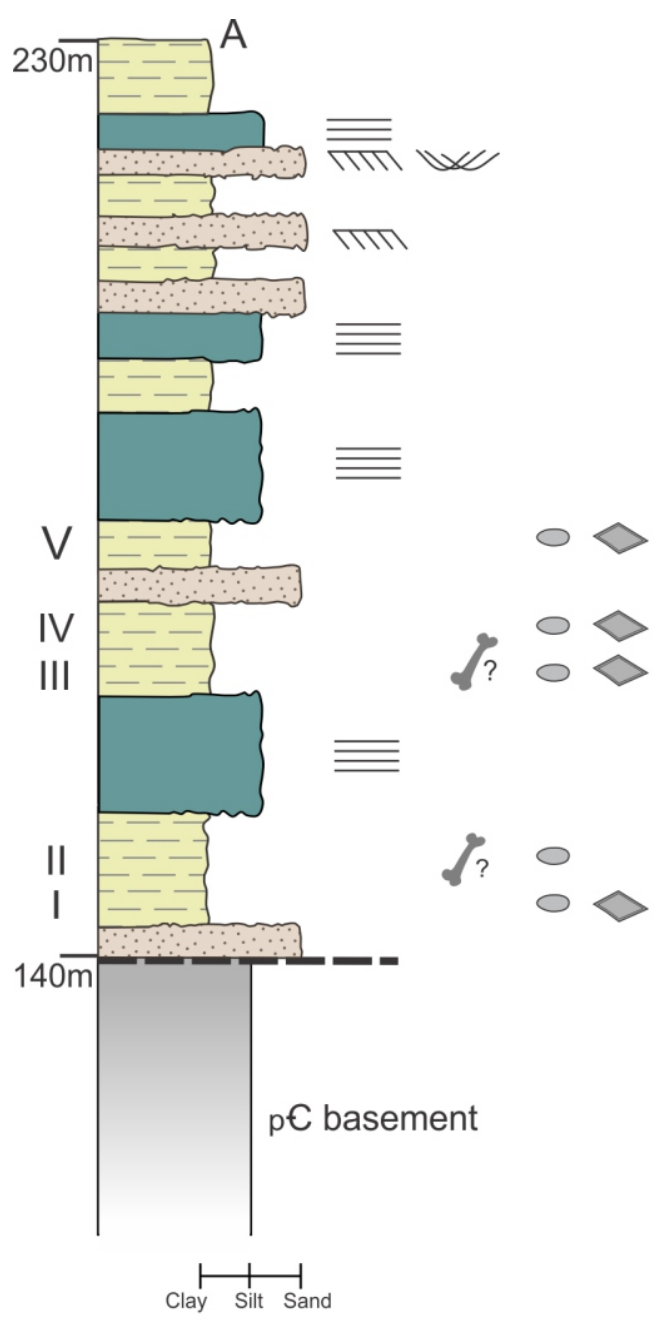

Albeit being found out of stratigraphic context, no bone was recovered from levels below the ostracod-bearing strata.

The ostracods are by far the most relevant finding reported herein. The specimens were recovered either as complete carapaces or as isolated valves, and are very common in the strata surveyed during this investigation. Some taxa found in the region of Lagoa dos Patos and Coração de Jesus are distinct from those recovered in southern portion of the Sanfranciscana Basin. The results discussed below are preliminary. A thorough study of the collected material is being conducted and will be reported elsewhere.
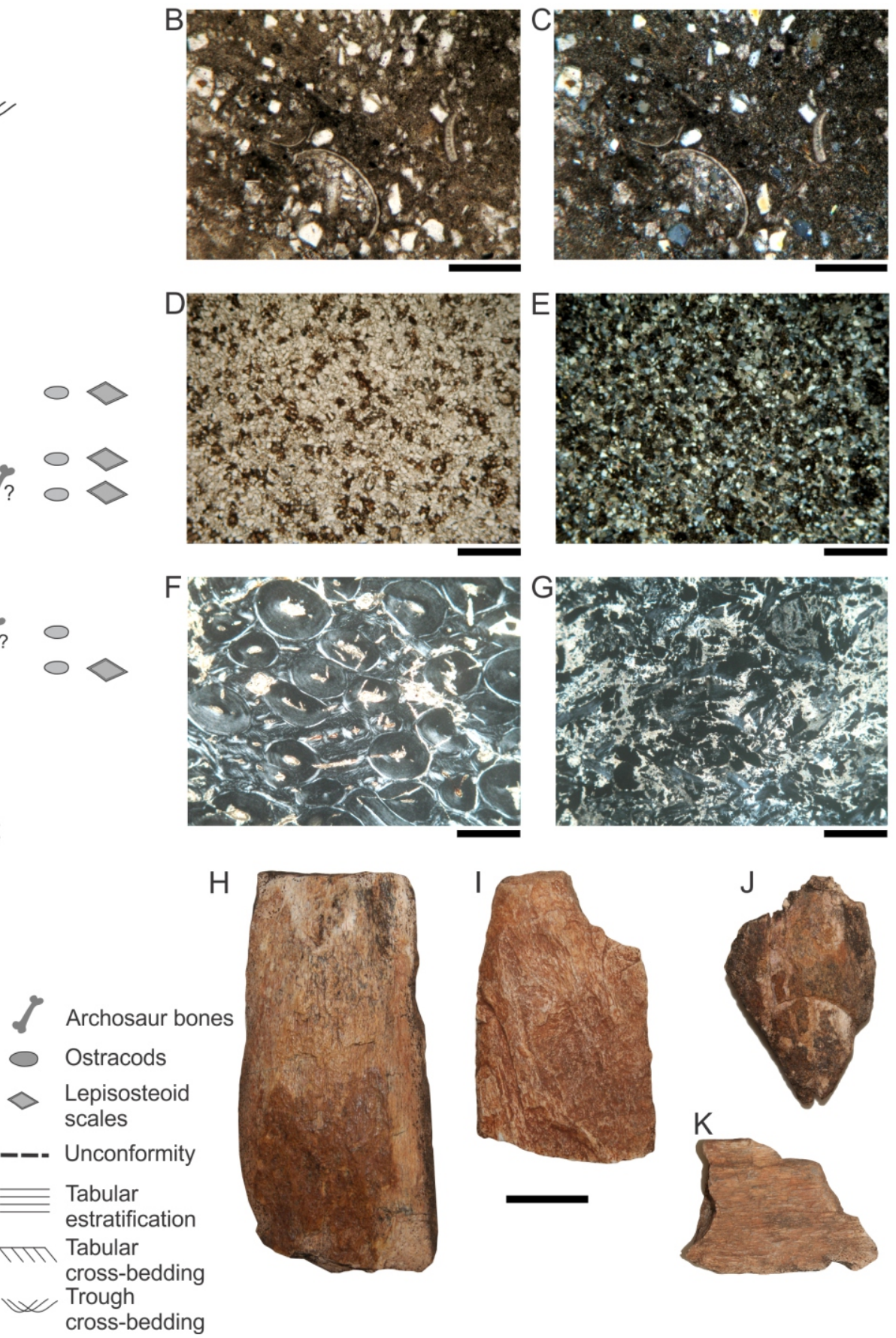

Figure 4-A, Generalized stratigraphic section of the Sanfransciana Basin in the region of Lagoa dos Patos and Coração de Jesus. B-C, petrographic section of the lithology 1 in normal and polarized light, respectively, showing ostracod carapaces. D-E, petrographic section of the lithology 3 in normal and polarized light, respectively. F, thin section of archosaurian bone, showing the Haversian remodeling. F, thin section of archosaurian bone showing the destructive diagenesis of the Haversian remodeling. $\mathrm{H}-\mathrm{K}$, isolated archosaurian bones (their exact level in the stratigraphic section is unknown). Scale bars $\mathrm{B}-\mathrm{G}: 500 \mu \mathrm{m}, \mathrm{H}-\mathrm{K}: 2 \mathrm{~cm}$. 
Among distinct taxa, two genera, namely llyocypris Brady \& Norman, 1889 and Fossocytheridea Swain \& Brown, 1964 (emend. Tibert et al., 2003), are more abundant and more frequently recovered from different levels of the sampled localities. Ilyocypris is more abundant in the level IV (several hundreds of specimens), and less frequent in the levels $V$ (>50 specimens) and I-III (>15 specimens). Fossocytheridea is particularly abundant in the horizon V (hundreds of specimens), I-III (> 30 specimens) and is absent in the level IV.

The carapaces of Ilyocypris recovered in this work are subrectangular (Figure $5 \mathrm{~A}-\mathrm{B}, \mathrm{E}-\mathrm{F}$ ) to subtriangular (Figure $C-D$ ). Their size is variable: $510-690 \mu \mathrm{m}$ long, 255-372 $\mu \mathrm{m}$ high, and the left valve (LV) partially overlaps (dorsal and posterior portions) the right (RV) one (Figure $5 F, H)$. The carapace dorsal margin is straight and slants posteriorly. The anterior cardinal angle is conspicuous, notably in the smaller carapaces (Figure 5C-D). The anterior margin is rounded, and significantly broader than the posterior one. The posterior margin also varies among distinct specimens: the larger individuals have oblique posterior margin, whereas in the smaller ones it is rounded and significantly smaller than the anterior margin. The ventral margin is slightly concave, with maximum concavity at the posterior half of the carapace length. The three tubercula typical to the genus are conspicuous. The anterior tuberculum (T1) is the smallest one, subtriangular to rounded, located slightly dorsal to the mid-height. The middle tubercle (T2) is also subtriangular to rounded. The posterior tubercle (T3) is the largest, ellipsoid, inclined $300-40$ o to the anteroposterior axis of the carapace. T1, T2 and T3 are separated by dorsoventral sulci, which is also typical to the genus. The ornamentation is reticulated.

The specimen assigned here to llyocypris show significant morphological variation, especially in the size and valve contour, which may be result from accentuated sexual dimorphism or the occurrence of more than one species of that genus in the sampled material. Yet, considering that the carapace ornamentation and the configuration of T1-T3 are rather conservative in distinct valves or carapaces, we provisionally maintain all specimens under the same generic identification, with open nomenclature, until a more detailed study is concluded. The genus Ilyocypris was reported in southern portions of the Sanfranciscana Basin (do Carmo et al., 2004), but the specimens are poorly preserved. According to the aforementioned authors, these carapaces bear pustulate ornamentation, not reticulate, as we described for the northern Minas Gerais specimens. A recent study based on more complete material from several localities within the Planalto Mata da Corda did not report the presence of Ilyocypris in that area (Leite et al., 2018).

The Ilyocypris specimens from the Sanfranciscana Basin also differs from previous records of that genus in the Aptian-Albian (?) of the Santana Formation, Araripe Basin (Antonietto, 2010). Unlike the material described in this paper, the specimens from
Araripe have low T1-T3, with poorly delimitated margins, and the posterior margin of the carapace is smaller and bear less conspicuous cardinal angle (Antonietto, 2010). The carapaces described here are more similar to those of Upper Cretaceous strata in Argentina (Musacchio \& Simeoni, 1991) and Brazil (Dias-Brito et al., 2001). The carapace size (specially the smaller ones), ornamentation and contour, including the straight and posteriorly inclined dorsal profile, the concave ventral margin and the conspicuous anterior cardinal angles, of the material from northern of Minas Gerais are comparable to those of Ilyocypris riograndensis Musacchio \& Simeoni, 1991, from the Neuquina Basin (minimally Coniacian for the ostracod-bearing levels), in Argentina (Musacchio \& Vallati, 2007; Carignano \& Varela, 2011). The main difference between them is the configuration of T3, which is significantly inclined in the specimens figured herein and mostly horizontal in I. riograndensis type material (Musacchio \& Simeoni, 1991). As the morphology of T3 is diagnostic to that species, the Ilyocypris from the Sanfranciscana Basin cannot be treated as conspecific.

The species llyocypris riograndensis has also been reported in the Araçatuba Formation in São Paulo State, indicating its presence in the Upper Cretaceous of Brazil (Gobbo et al., 1999). Dias-Brito et al. (2001) reported several Ilyocypris species from the Adamantina Formation, including I. cf. wichmanni Musacchio, 1973, I. cf. riograndensis and two subspecies of I. bauruensis Dias-Brito et al., 2001. Some Ilyocypris described here (Figure 5C-D) have close affinities with I. baurensis rectidorsata Dias-Brito et al., 2001 (estampa III, fig. 2) due to the shape of the carapace and the general morphology of T1-T3.

The cytherideid Fossocytheridea Swain \& Brown, 1964 (emend. Tibert et al., 2003) is reported in the Sanfranciscana Basin for the first time. The carapaces here assigned to that genus (Figure 5I-T) are subrectangular in lateral view, with variable length (620-845 $\mu \mathrm{m})$. RV overlaps LV for most of its extension. The dorsal margin is straight and inclined posteroventrally in RV, and rather convex in LV. The hinge is antimerodont. The anterodorsal sulcus, typical for the genus, is broad and vertical, bounding anteriorly the conspicuous centroposterior swelling. The ocular tubercle is located anterior to the anterodorsal sulcus. The carapace is widest at the posterior third. RV is highest at the anterior cardinal angle, and LV at midlength or posterior to the anterodorsal sulcus. The anterior margin is rounded, with a compression along its anterior margin; and the posterior margin asymmetrically rounded (ventroposteriorly projected, especially in female LV). The ventral margin bears a posterior concavity in RV, and is straight in LV. A posteroventral rounded tubercle is noted on the left valve. The ornamentation is reticular, notably in marginal areas of the carapace. There is conspicuous sexual dimorphism: males are larger, with lower cardinal angle, and their posterior margin is more symmetrically rounded (compared with Figure 5P-Q). 
The cytherideid Fossocytheridea is common in Upper Cretaceous strata within marginal basins in Brazil (Bergue et al., 2011; Fauth et al., 2012; Piovesan et al., 2015), and its occurrence has been used as marker to lagoonal, brackish and marine paleoenvironments (e.g. Swain \& Brown, 1964; Tibert et al., 2003; Santos Filho et al., 2015). The specimens studied in this paper share the diagnostic characters of Fossocytheridea ventrotuberculata, including the subrectangular carapace, valve reversal and a tubercle in the posteroventral region of the left valve (Bergue et al., 2011). Additional characters shared by that species and the specimens described herein encompasses sexual dimorphism, posterior 'rib' and the carapace dimensions, including length-height ratio (0.50). The main difference between them is the presence of extensive reticulation in the outer surface of the carapace, rather than extensive punctae and minor reticulation. Despite this feature was not assigned as diagnostic to $F$. vetrotuberculata, we provisionally refer the material of the Sanfranciscana Basin to Fossocytheridea sp., until a more detailed study is conducted.
Yet, as mentioned by Bergue et al. (2011), there is visible variation in the morphology of $F$. ventrotuberculata, and future studies can test if Fossocytheridea from the Sanfranciscana Basin belongs to that species.

The presence of reticulation has been recorded in other species of Fossocytheridea, including the type-species $F$. lenoirensis Swain and Brown 1964, and F. kirklandi Tibert et al., 2003. Yet, these and other Fossocytheridea species (Swain \& Brown, 1964; Colin et al., 1996; Tibert et al., 2003), including some described from the Upper Cretaceous marginal basins in Brazil (Bergue et al., 2011; Fauth et al., 2012; Piovesan et al., 2014, 2015), differ from the material described in this paper in distinct aspects of the carapace morphology. The earliest Fossocytheridea sensu Tibert et al. (2003), which includes specimens from the Aptian of Portugal (Damotte et al., 1988; Damotte et al., 1990), is also distinct from those of the Sanfranciscana Basin in details of the carapace shape and the absence of valve reversal, sexual dimorphism and carapace reticulation.

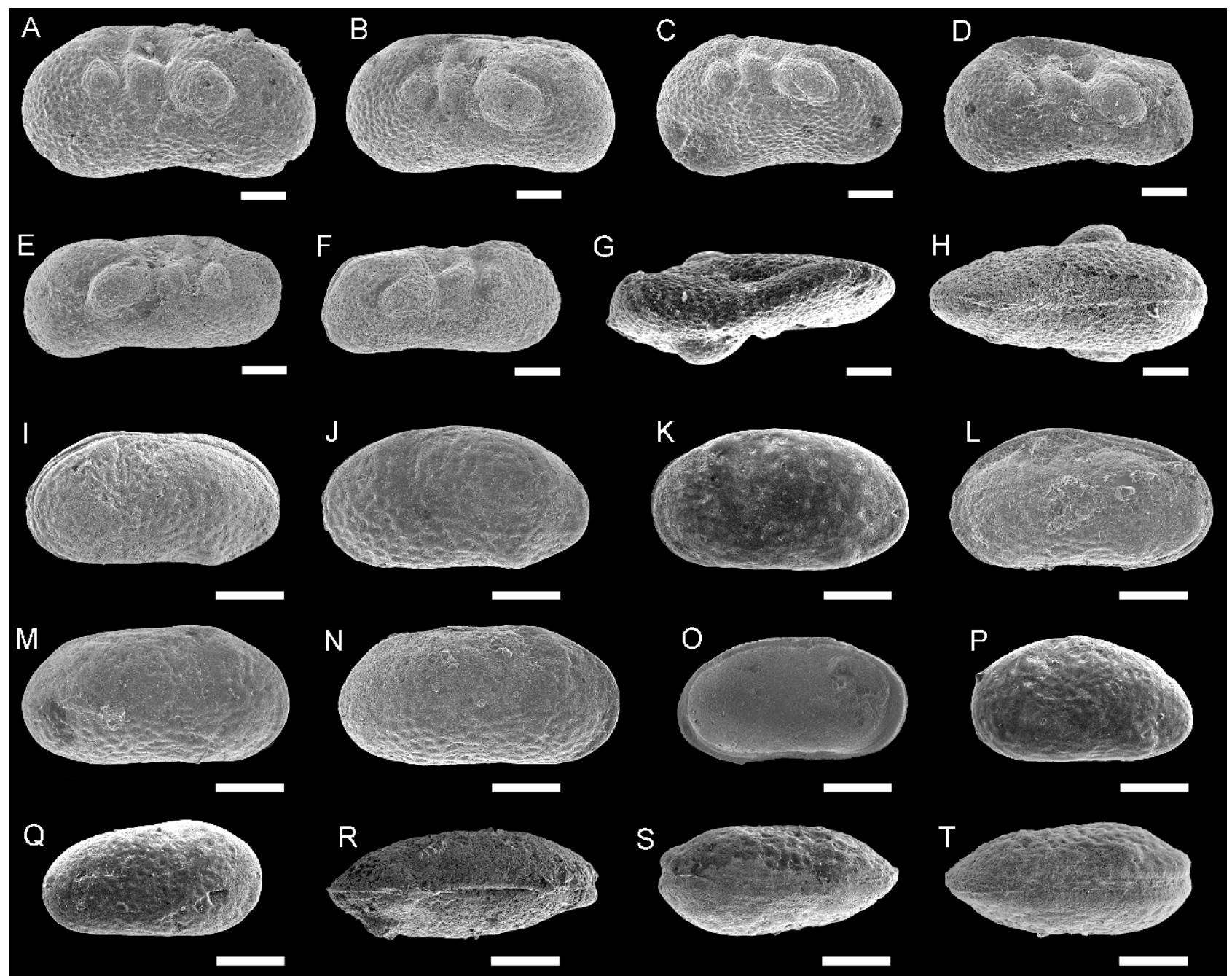

Figure 5 - Most abundant ostracods sampled from the horizons indicated in the Figure 4, including llyocypris (A-H) and Fossocytheridea (I-T). A, IGC-P 0053/11 (left); B, IGC-P 0053/10 (left); C, IGC-P 0053/06 (left valve); D, IGC-P 0053/12 (left); E, IGC-P 0053/17 (right); F, IGC-P 0052/05 (right); G, IGC-P 0053/141 (dorsal); H, IGC-P 0053/142 (ventral); I, IGC-P 0053/143 (male, left); J, IGC-P 0053/34 (male, left); K, IGC-P 0053/143 (male, left); L, IGC-P 0053/08 (male, left); M, IGC-P 0053/09 (male, right); N, IGC-P 0053/32 (male, right); O, IGC-P 0178/01 (left valve, internal); P, IGC-P 0053/144 (female, left); Q, IGC-P 0053/145 (female, right); R, IGC-P 0053/146 (dorsal, note RV overlapping LV); S, IGC-P 0052/36 (dorsal, note RV overlapping LV); T, IGC-P 0052/36 (ventral). Scale bar A-H: $200 \mu \mathrm{m} ; \mathrm{I-T:} 100 \mu \mathrm{m}$. 


\section{Implications for the Sanfranciscana Basin}

The geological and paleontological research in the Sanfranciscana Basin is increasing in the last few years (Bittencourt et al., 2015, 2017, 2018; Mescolotti, 2015, 2017; Carvalho \& Santucci, 2018; Leite et al., 2018). Yet, the outcrops in northern Minas Gerais are less studied than those in southern localities. In fact, a large amount of data about this area remains unpublished (PiresDomingues, 2009; Silva, 2013). This preliminary report fills partially information gaps on its geology and fossil record.

Concerning ostracods, these are known from the Quiricó Formation since early works conducted in the Planalto Mata da Corda. Barbosa et al. (1970) mentioned the genera Eucyproides [sic], Heterocypris Claus, 1893, Candonopsis Vávra, 1891 and Darwinula Brady \& Robertson, 1870; Sgarbi (1997) later reported and figured Pattersoncypris (?), Darwinula cf. martinsi Silva, 1978 , Darwinula sp., Cypridea sp. and Ilyocypris sp.; and Delicio et al. (1998) recorded Darwinula and Cypridaceae from João Pinheiro. In these studies, no detailed information on the fossil localities and exact fossiliferous strata was provided. In a more detailed study, Do Carmo et al. (2004) identified the genera Harbinia Tsao, 1959, Brasacypris Krömmelbein, 1965, Cypridea Bosquet, 1852, Bisulcocypridea (Sohn, 1969), Ilyocypris Brady \& Norman, 1889, several ontogenetic instars of Darwinula and Wolburgiopsis Uliana \& Musacchio, 1978 in Carmo do Paranaíba and at BR-040 road, near João Pinheiro. A recent detailed paper report several species of Harbinia, Brasacypris, Cypridea, Penthesilenula Rossetti \& Martens, 1998, Alicenula Rossetti \& Martens, 1998, Neuquenocypris Musacchio, 1973 and Timiriasevia sanfranciscanensis Leite et al., 2018 from João Pinheiro and Presidente Olegário (Leite et al., 2018). In comparison with previous works, our results suggest that the distribution of ostracods within the Sanfranciscana Basin is not uniform. Ilyocypridids, for instance, occur in some outcrops near João Pinheiro, but not at Carmo do Paranaíba and Presidente Olegário (do Carmo et al., 2004; Leite et al., 2018). In Lagoa dos Patos and Coração de Jesus, ilyocypridids are very common. The genus Fossocytheridea, on the other hand, is reported in the Sanfranciscana Basin for the first time and is so far restricted to northern localities.

The association between Fossocytheridea (sensu Tibert et al., 2003) and Ilyocypris has also been recorded in oligohaline environments of Santos Basin in Brazil (Fauth et al., 2012), and the Neuquén Group in Río Negro and Neuquén, Argentina (Musacchio, 1973). This latter can be compared to the strata of the Neuquén Group in El Zampal (Uliana \& Musacchio, 1978), where Ilyocypris is abundant, and the association with typical brackishwater ostracods is probably related to oligohaline continental environment, not necessarily with persistent marine connection (Musacchio, 1973). So far, the lack of unequivocal marine elements in the association described in this paper suggests that some levels of the
Sanfranciscana Basin in northern Minas Gerais were deposited in brackish-water continental environment, not lagoon. Interestingly, where Ilyocypris is more abundant (level IV), no carapace of Fossocytheridea has been recovered, suggesting probable vertical variation of salinity.

The strata of the Quiricó Formation in southern areas of the Sanfranciscana Basin have been dated as Valanginian to Aptian with basis on ostracods and palynomorphs (Lima, 1979; do Carmo et al., 2004; Leite et al., 2018). This indicates that this unit encloses diachronous paleobiotas. Previous studies in the region of Ibiaí, Lagoa dos Patos and Coração de Jesus have assigned the fossiliferous lacustrine strata to the Lower Cretaceous Quiricó Formation (Zaher et al., 2011; Bittencourt et al., 2017; Carvalho \& Santucci, 2018). Albeit the strata of northern and southern areas of the Areado Group are geologically similar, such an assignment requires further scrutiny. Considering that Fossocytheridea ranges from Aptian to Maastrichtian (Tibert et al., 2003), its occurrence in the Sanfranciscana Basin raises distinct hypothesis for the chronostratigraphy of the lacustrine strata of the Sanfranciscana Basin. The first one is that horizons sampled here were at least partially deposited during Aptian, which would correspond to the age of the upper levels of the Quiricó Formation (Lima, 1979; Arai et al., 1995; do Carmo et al., 2004; Leite et al., 2018). The alternative hypothesis is that the levels sampled for this study are younger than that implied by a possible correlation with the fossil record from the Planalto Mata da Corda. In this case, based on the association of Fossocytheridea and Ilyocypris in Upper Cretaceous strata in Brazil and Argentina, and the Santonian age of F. ventrotuberculata (with possible affinities with the material described here), the levels studied herein can possibly span into the Late Cretaceous. Interestingly, the titanosaur Tapuiasaurus macedoi has been nested within Late Cretaceous clades in several phylogenetic scenarios (Zaher et al., 2011; Lacovara et al., 2014; Wilson et al., 2016).

Yet, the time range of both Fossocytheridea and Ilyocypris are long, hampering more accurate dating. Further data, including a more complete taxonomic study of the ostracods from the localities discussed here, are required to elucidate the age of the Sanfranciscana Basin in northern Minas Gerais.

\section{ACKNOWLEDGEMENTS}

We acknowledge the CPMTC-IGC-UFMG and the Center of Microscopy (UFMG) for assistance with sample preparation and SEM. Enelise K. Piovesan and Cristianini T. Bergue are thanked for reviewing earlier drafts of this manuscript, greatly improving its final version. This research was funded by FAPEMIG, grants PEP-01114-15, APQ-01110-15, PPM-00304-18 to JSB. It also benefited from the equipment acquired from Programa Petrobras de Formação de Recursos Humanos (PRH-PB 238). 


\section{REFERENCES}

Alkmin, F.F., Martins-Neto, M.A., 2001. A Bacia Intracratônica do São Francisco: arcabouço estrutural e cenários evolutivos, In: Pinto, C.P., Martins-Neto, M.A. (Eds.), Bacia do São Francisco: Geologia e Recursos Naturais. SBG, Belo Horizonte, pp. 9-30.

Antonietto, L.S., 2010. Ostracodes da Formação Santana (Cretáceo Inferior, Aptiano Superior), Bacia do Araripe, NE-Brasil: taxonomia, distribuição estratigráfica e paleoecologia. Tese de Mestrado, Universidade de Brasília. 59 pp.

Arai, M., Dino, R., Milhomem, P.S., Sgarbi, G.N.C., 1995. Micropaleontologia da Formação Areado, Cretáceo da Bacia Sanfranciscana: estudo dos ostracodes e palinologia. In: XIV Congresso Brasileiro de Paleontologia, Atas, Uberaba, p. 2-3.

Barbosa, O., 1965. Geologia econômica e aplicada a uma parte do Planalto Central brasileiro. In: XIX Congresso Brasileiro de Geologia, Anais, Rio de Janeiro, p. 1-11.

Barbosa, O., Braun, O.P.G., Dyer, R.C., da Cunha, C.A.B.R., 1970. Geologia da região do Triângulo Mineiro. Boletim da Divisão de Fomento da Produção Mineral 136, 1-140.

Bergue, C.T., Fauth, G., Vieira, C.E.L., dos Santos, A.S., 2011. New species of Fossocytheridea Swain \& Brown 1964 (Ostracoda, Crustacea) in the Upper Cretaceous of Santos Basin Brazil. Revista Brasileira de Paleontologia 14, 149-156.

Bittencourt, J.S., Gallo, V., Rodrigues, G.A., 2017. Lepisosteoid-type fish scales in the Barremian-Aptian (Lower Cretaceous) of the Sanfranciscana Basin, Southeastern Brazil. Cretaceous Research 70, 1-7.

Bittencourt, J.S., Kuchenbecker, M., Vasconcelos, A.G., Meyer, K.E.B., 2015. O registro fóssil das coberturas sedimentares do Cráton do São Francisco em Minas Gerais. Geonomos 23, 39-62.

Bittencourt, J.S., Rohn, R., Gallego, O.F., Monferran, M.D., Uhlein, A., 2018. The morphology and systematics of the clam shrimp Platyestheria gen. nov. abaetensis (Cardoso) (Crustacea, Spinicaudata) from the Lower Cretaceous of the Sanfranciscana Basin, southeast Brazil. Cretaceous Research 91, 274-286.

Bosquet, J., 1852. Description des entomostracés fossiles des terrains tertiaires de la France e de la Belgique. Mémoires Couronnés et Mémoires des Savants Étrangers 24, 1-142

Brady, G.S., Norman, A.M., 1889. A monograph of the marine and freshwater Ostracoda of the North Atlantic and of North-Western Europe. Section I. Podocopa. The Scientific Transactions of the Royal Dublin Society, Series 24, 63-270, PIs. 278-223.

Brady, G.S., Robertson, D., 1870. The Ostracoda and Foraminifera of tidal rivers: with analysis and descriptions of the Foraminifera. The Annals and Magazine of Natural History 6, 1-33.

Campos, J.E.G., Dardenne, M.A., 1994. A Glaciação Neopaleozóica na Porção Meridional da Bacia Sanfranciscana. Revista Brasileira de Geociências 23, 65-76.
Campos, J.E.G., Dardenne, M.A., 1997. Estratigrafia e Sedimentação da Bacia Sanfranciscana: uma revisão. Revista Brasileira de Geociências 27, 227-240.

Cardoso, R.N., 1971. Contribuição ao estudo da Formação Areado: estratigrafia e descrição dos filópodos fósseis. Arquivos do Museu de História Natural 1, 9-47.

Carignano, A.P., Varela, J.A., 2011. Ostrácodos (Custacea) de la Formación Allen (Cretácico Tardio), Cuenca Neuquina, Argentina. Revista Brasileira de Paleontologia 14, 169-178.

Carvalho, I.S., Bertolino, L.C., Borghi, L.F., Duarte, L., Carvalho, M.S.S., Cassab, R.C.T., 1994. Range charts of the fossils of the Cretaceous interior basins - The São Francisco Basin, In: Beurlen, G., Campos, D.A., Viviers, M.C. (Eds.), Stratigraphic range of Cretaceous megaand microfossils of Brazil. UFRJ, Rio de Janeiro, pp. 333-352.

Carvalho, I.S., Kattah, S., 1998. As pegadas fósseis do paleodeserto da Bacia Sanfranciscana (Jurássico Superior-Cretáceo Inferior, Minas Gerais). Anais da Academia Brasileira de Ciências 70, 53-67.

Carvalho, J.C., Santucci, R.M., 2018. New dinosaur remains from the Quiricó Formation, Sanfranciscana Basin (Lower Cretaceous), Southwestern Brazil. Cretaceous Research 85, 20-27.

Carvalho, M.S.S., Maisey, J.G., 2008. New occurrence of Mawsonia (Sarcopterygii: Actinistia) from the Early Cretaceous of the Sanfranciscana Basin, Minas Gerais, southeastern Brazil. Geological Society Special Publication 295, 109-144.

Chaves, M.L.S.C., Andrade, K.W., 2013. FOLHA CORAÇÃO DE JESUS - SE-23-X-A-V. CODEMIG, Belo Horizonte.

Claus, C., 1893. Beiträge zur Kenntnis der SüsswasserOstracoden, I. Über den Körper- und Gliedmassenbau der Cypriden. Arbeiten aus dem Zoologischen Institut der Universität Wien und der Zoologischen Station in Triest 10, 147-216.

Colin, J.-P., Tambareau, Y., Krasheninnikov, V.A., 1996. Ostracodes limniques et lagunaires dans le crétacé supérieur du Mali (Afrique de l'Ouest): systématique, paléoécologie et affinités paléobiogéographiques. Revue de Micropaléontologie 39, 211-222.

Costa, R.D., Uhlein, G.J., Kuchenbecker, M., Romano, A.W., Knauer, L.G., Marques, C.S.S., Hoerlle, F.O., 2013. FOLHA VÁRZEA DA PALMA - SE.23-X-C-IV. Codemig, Belo Horizonte.

CPRM/CODEMIG, 2014. Mapa Geológico do Estado de Minas Gerais. CPRM/CODEMIG.

Damotte, R., Cabral, M.C.C., Berthou, P.-Y., 1990. Ostracodes aptiens de la coupe de São João da Venda (Algarve Oriental Portugal). Revue de Micropaléontologie 33, 73-91.

Damotte, R., Ramalho, M., Rey, J., 1988. Les ostracodes aptiens de l'Algarve Occidental (Portugal) Revue de Micropaléontologie 31, 38-48.

Delicio, M.P., Barbosa, E.M., Coimbra, J.C., Vilella, R.A., 1998. Ocorrência de conchostraceos e ostracodes em sedimentos Pós-Paleozóicos da Bacia do Alto 
Sanfranciscana, Olhos d'Água, noroeste de Minas Gerais, Brasil. Acta Geologia Leopoldensia 46/47, 13-20.

Dias-Brito, D., Musacchio, E.A., Castro, J.C., Maranhão, M.S.A., Suarez, J.M., Rodrigues, R., 2001. Grupo Bauru: uma unidade continental do Cretáceo do Brasil - concepçõe $s$ base adas e m dados micropaleontológicos, isotópicos e estratigráficos. Revue Paléobiologique 20, 245-304.

Dias-Brito, D., Pessagno Jr., E.A., Castro, J.C., 1999. Novas considerações cronoestratigráficas sobre o silexito a radiolários do sul da Bacia Sanfranciscana, Brasil, e a ocorrência de foraminíferos planctônicos nestes depósitos. In: V Simpósio sobre o Cretáceo do Brasil, Boletim de Resumos, Rio Claro, p. 567-575.

do Carmo, D.A., Tomassi, H.Z., Oliveira, S.B.S.G., 2004. Taxonomia e distribuição estratigráfica dos ostracodes da Formação Quiricó, Grupo Areado (Cretáceo Inferior), Bacia Sanfranciscana, Brasil. Revista Brasileira de Paleontologia 7, 139-149.

Duarte, L., 1997. Vegetais do Cretáceo Inferior (Aptiano) da Formação Areado, município de Presidente Olegário, Estado de Minas Gerais. Anais da Academia Brasileira de Ciências 69, 495-503.

Fauth, G., Santos, A.S., Vieira, C.E.L., Bergue, C.T., Musacchio, E.A., Ferreira, E.P., Escamilla, J.H., Carvalho, M.A., Viviers, M.C., Fauth, S.B., 2012. Bioestratigrafia integrada do Cretáceo Superior da Bacia de Santos: ostracodes, carófitas e palinomorfos. Boletim de Geociências da Petrobrás 20, 229-258.

Gobbo, S.R., Petri, S., Bertini, R.J., 1999. Ocorrências de Ostrácodes na Formação Adamantina do Grupo Bauru, Cretáceo Superior da Bacia do Paraná e possibilidades de correlação com depósitos isócronos argentinos. Parte I - Família Ilyocyprididae. Acta Geológica Leopoldensia 23, 3-13.

Hagen, E., Kelley, S.P., Dypvik, H., Nilsen, O., KjØLhamar, B., 2001. Direct dating of authigenic K-feldspar overgrowths from the Kilombero Rift of Tanzania. Journal of the Geological Society 158, 801-807.

Kattah, S.S., 1991. Analise Faciológica e Estratigráfica do Jurássico Superior/Cretácio Inferior na Porção Meridional da Bacia Sanfranciscana, Oeste do Estado de Minas Gerais. Tese de Mestrado, Universidade Federal de Ouro Preto. 227 pp.

Kattah, S.S., Koutsoukos, E.A.M., 1992. Ocorrencias de radiolários em fácies de origem marinha no Mesozóico da Bacia Sanfranciscana. Revista da Escola de Minas 45, 214.

Knauer, L.G., Fantinel, L.M., Costa, R.D., Romano, A.W., Santos Júnior, A.G., Horta, R.M., 2013. FOLHA IBIAÍ SE.23-X-A-IV. CODEMIG, Belo Horizonte.

Krömmelbein, K., 1965. Ostracoden aus der nicht-marine Unter-Kreide ('Westafrikanischer Wealden') des Congo-Kusttenbeckens. Meyniana 15, 59-74.

Lacovara, K.J., Lamanna, M.C., Ibiricu, L.M., Poole, J.C., Schroeter, E.R., Ullmann, P.V., Voegele, K.K., Boles, Z.M., Carter, A.M., Fowler, E.K., Egerton, V.M., Moyer, A.E., Coughenour, C.L., Schein, J.P., Harris, J.D.,
Martínez, R.D., Novas, F.E., 2014. A Gigantic, Exceptionally Complete Titanosaurian Sauropod Dinosaur from Southern Patagonia, Argentina. Scientific Reports 4, 1-9.

Leite, A.M., Do Carmo, D.A., Ress, C.B., Pessoa, M., Caixeta, G.M., Denezine, M., Adorno, R.R., Antonietto, L.S., 2018. Taxonomy of limnic Ostracoda (Crustacea) from the Quiricó Formation, Lower Cretaceous, São Francisco basin, Minas Gerais State, Southeast Brazil. Journal of Paleontology 92, 661-680.

Lima, M.R., 1979. Palinologia dos calcários laminados da Formação Areado, Cretáceo de Minas Gerais. In: 2o Simpósio Regional de Geologia, 1, Rio Claro, p. 203-216.

Maraschin, A.J., Mizusaki, A.M., Zwingmann, H., Sgarbi, G.N.C., 2016. K-Ar dating of authigenic minerals in siliciclastic sequences: an example from the south Sanfranciscana Basin.

Martins-Neto, R.G., 1996. Reinterpretação da venação e revisão das categorias taxonômicas superiores de Gondvanoptilon brasiliensis ( = G. brasiliense nom. transl.) Rösler, Rohn \& Albamonte, inseto do Paleozóico da Bacia do Paraná e Saucrolus silvai Santos, artrópode do Cretáceo da Bacia Sanfranciscana. Revista Universidade de Guarulhos, Série Geociências 1, 42-45.

Mescolotti, P.C., 2015. Paleocorrentes e paleogeografia do Grupo Areado, Cretáceo Inferior da Bacia Sanfranciscana. Tese de BSc, UNESP. 60 pp.

Mescolotti, P.C., 2017. Sistemas eólicos da Formação Três Barras, Cretáceo da Bacia Sanfranciscana. Tese de MSc, 73 pp.

Mescolotti, P.C., Varejão, F.G., Assine, M.A., 2015. Associações de fácies sedimentares e ambientes deposicionais da Formação Quiricó, Cretáceo Inferior da Bacia Sanfranciscana. In: Geosudeste, Anais, Campos do Jordão, p. 1-2.

Musacchio, E.A., 1973. Charophytas y ostrácodos no marinos del Grupo Neuquén (Cretácico Superior) en algunos afloramientos de las provincias de Río Negro y Neuquén, República Argentina. Revista del Museo de La Plata (Nueva Serie), Paleontología 8, 1-32.

Musacchio, E.A., Simeoni, M., 1991. Taxonomy of some Cretaceous non-marine ostracods of palaeobiogeographical interest. Neues Jahrbuch für Geologie und Paläontologie - Abhandlungen 180, 349-389.

Musacchio, E.A., Vallati, P., 2007. Late Cretaceous non marine microfossil of the Plottier Formation (Cretaceous) at Zampal, Argentina. Cuadernos del Museo Geominero 8, 273-278.

Pessagno Jr., E.A., Dias-Brito, D., 1996. O silexito a radiolários do sul da Bacia Sanfranciscana, Brasil: idade, origem e significado. In: IV Simpósio sobre o Cretáceo do Brasil, Boletim, Águas de São Pedro, p. 213-221.

Pessagno Jr., E.A., Dias-Brito, D., Castro, J.C., 1997. Tectonostratigraphic significance of radiolarian chert 
in Lower Cretaceous continental sequence, Minas Gerais, Brazil. In: GSA Annual Meeting, 29, Utah, p. 374.

Piovesan, E.K., Cabral, M.C.C., Boavida, E.A., Colin, J.-P., Fauth, G., 2015. Fossocytheridea Swain \& Brown and Perissocytheridea Stephenson (Ostracoda): insights into paleosalinity gradients of Late Cretaceous deposits from Brazil and Portugal. Revista Brasileira de Paleontologia 18, 21-30.

Piovesan, E.K., Cabral, M.C.C., Colin, J.-P., Fauth, G., Bergue, C.T., 2014. Ostracodes from the Upper Cretaceous deposits of the Potiguar Basin, northeastern Brazil: taxonomy, paleoecology and paleobiogeography. Part 2: Santonian-Campanian. Carnets de Géologie 14, 315-351.

Pires-Domingues, R.A., 2009. Paleogeografia do Alto de Paracatu: o registro geológico dos bone-beds de dinossauros da Bacia Sanfranciscana. Tese de Mestrado, Universidade de São Paulo. 110 pp.

Romano, A.W., Knauer, L.G., Costa, R.D., Oliveira, D.V., Barroso, M.F., Serrano, P.M., 2013. FOLHA PIRAPORA SE.23-X-C-I. Codemig, Belo Horizonte.

Rossetti, G., Martens, K., 1998. Taxonomic revision of the Recent and Holocene representatives of the Family Darwinulidae (Crustacea, Ostracoda), with a description of three new genera. Bulletin de L'Institut Royal des Sciences Naturelles de Belgique 68, 55-110.

Santos Filho, M.A.B., Piovesan, E.K., Fauth, G., Srivastava, N.K., 2015. Paleoenvironmental interpretation through the analysis of ostracodes and carbonate microfacies: study of the Jandaíra Formation, Upper Cretaceous, Potiguar Basin. Brazilian Journal of Geology 45, 23-34.

Santos, M.E.C.M., 1971. Um nôvo artrópodo da Formação Areado, Estado de Minas Gerais. Anais da Academia Brasileira de Ciências 43, 415-420.

Scorza, F.P., Silva Santos, R., 1955. Ocorrência de folhelho fossilífero no município de Presidente Olegário, Minas Gerais. Boletim do Departamento Nacional de Produção Mineral - Divisão de Geologia e Mineralogia $155,1-27$.

Sgarbi, G.N.C., 1997. Aspectos paleogeográficos e sedimentológicos do Mesozóico no oeste do estado de Minas Gerais Tese de Doutorado, Universidade de Brasília. 224 pp.

Sgarbi, G.N.C., 2000. The Cretaceous Sanfranciscan Basin, Eastern plateau of Brazil. Revista Brasileira de Geociências 30, 450-452.

Sgarbi, G.N.C., Horn, H.A., Grossi Sad, J.H., 1993. Aspectos químicos e isotópicos dos sedimentos lacustres da Formação Areado, Bracia cretácica do São Francisco, MG. Anais da Academia Brasileira de Ciências 65, 265-270.

Sgarbi, G.N.C., Sgarbi, P.B.A., Campos, J.E.G., Dardenne, M.A., Penha, U.C., 2001. Bacia Sanfranciscana: o registro Fanerozóico da Bacia do São Francisco In: Pinto, C.P., Martins-Neto, M.A. (Eds.), Bacia do São Francisco: Geologia e Recursos Naturais. SBG, Belo Horizonte, pp. 93-138.
Silva, A.J.P., Lopes, R.C., Vasconcellos, A.M., Bahia, R.B.C., 2003. Bacias Sedimentares Paleozóicas e MesoCenozóicas Interiores, In: Bizzi, L.A., Schobbenhaus, C., Vidotti, R.M., Gonçalves, J.H. (Eds.), Geologia, Tectônica e Recursos Minerais do Brasil. CPRM, Brasília, pp. 55-85.

Silva, M.D., 1978. (Cretáceo Inferior - Grupo Araripe Nordeste do Brasil III Ostracodes da Formação Santana - nova espécie do gênero Darwinula Brady \& Robertson, 1885. In: 30th Congresso Brasileiro de Geologia, 2, p. 1028-1031.

Silva, R.R., 2013. Descrição osteológica e posicionamento filogenético de um terópode (Dinosauria, Saurischia) do Cretáceo Inferior da Bacia Sanfranciscana, município de Coração de Jesus, Minas Gerais, Brasil. Tese de Mestrado, Universidade de São Paulo. 121 pp.

Silva Santos, R., 1985. Laeliichthys ancestralis, novo gênero e espécies de Osteoglossiformes do Aptiano da Formação Areado, estado de Minas Gerais, Brasil, In: Campos, D.A., Ferreira, C.S., Brito, I.M., Viana, C.F. (Eds.), Paleontologia e Estratigrafia, Coletânea de Trabalhos Paleontológicos. DNPM, Brasília, pp. 161-167.

Sohn, I.G., 1969. Nonmarine ostracodes of Early Cretaceous age from Pine Valley Quadrangle Nevada. Contributions to Paleontology, Geological Survey Professional Paper 643-B, 1-14.

Swain, F.M., Brown, P.M., 1964. Cretaceous Ostracoda from wells in the Southeastern United States. North Carolina Department of Conservation and Development, Division of Mineral Resources Bulletin 78, 1-55.

Tibert, N.E., Colin, J.-P., Leckie, R.M., Babinot, J.-F., 2003. Revision of the ostracode genus Fossocytheridea Swain and Brown 1964: Mesozoic ancestral root for the modern eurytopic Cyprideis Jones. Micropaleontology 49, 205-230.

Tsao, L.P., 1959. Harbinia Tsao, 1959, In: Nechayeva, M.A., Liu, Z.Y., Su, D.Y., Shou, Z.X., Tian, K.Z., Tsao, L.P. (Eds.), Ostracods of Lower chalk deposit of valley Sunlyao. Ministry of Geology, People's Republic of China, Series B (Stratigraphy and Palaeontology), 1(2), pp. 48-49.

Uhlein, A., Reis Junior, W., Freitas, A.R., Uhlein, G.J., Ávila, M.A.B., 2013. FOLHA UBAÍ - SE.23-X-A-I. Codemig, Belo Horizonte.

Uliana, M.A., Musacchio, E.A., 1978. Microfósiles calcáreos no-marinos del Cretácico superior en Zampal, Província de Mendoza, Argentina. Ameghiniana 15, 111-135.

Vávra, W., 1891. Monographie der Ostracoden Böhmens. A r chiv der Naturwissen schaften Landesdurchforschung von Böhmen 8, 1-118.

Wilson, J.A., Pol, D., Carvalho, A.B., Zaher, H., 2016. The skull of the titanosaur Tapuiasaurus macedoi (Dinosauria: Sauropoda), a basal titanosaur from the Lower Cretaceous of Brazil. Zoological Journal of the Linnean Society 178, 611-662. 